DOI: $10.15193 /$ zntj/2020/123/342

\title{
MAGDALENA NIEWCZAS-DOBROWOLSKA, TADEUSZ SIKORA \\ EVALUATION OF RISK PERCEPTION OF SELECTED FOOD HAZARDS USING PERCEIVED FOOD RISK INDEX (PFRI)
}

\begin{abstract}
S u m m a ry
Risk perception depends on many socio-economic and psychological factors. It is very important to know how consumers perceive risks associated with food hazards such as: hormone residues, GM food, food preservatives and trans fats. In the paper, there is presented a tool to measure risk perception a Perceived Food Risk Index (PFRI). The survey was conducted among 152 young consumers in three regions in Poland, in 2016.

The objective of the paper was to show how consumers perceive some selected food hazards. It has been found that the highest perceived risk was associated with determination whether the hazard is natural or caused by human activities - the sum of average ratings was 15.7. In the case of scientists' knowledge about hazard - the sum of average ratings was 14.7. The lowest perceived risk was associated with the correlation between the severity of hazard and the quantity of consumed food - the sum of average ratings was 11.2, and with the supervision/control of food consumption - the sum of average ratings was 11.6. The survey performed highlights the need for and the importance of measuring and collecting information about the food risk perception by consumers. The perception of food risk impacts their food choices and behaviour when food hazard appears.
\end{abstract}

Key words: risk perception, food, consumer, Perceived Food Risk Index (PFRI)

\section{Introduction}

Risk has become part of our everyday life. Risk-taking is inherent in man's nature and also it boots innovation and development [19]. Ulrich Beck, author of the book "World Risk Society", indicates that the analysis of society response to risk is very important $[7,16]$. Consumers perceive the risk associated with a product from biotechnology as high. They do not see the correlation between the biotechnology used in food production and the advantages thereof [14]. Liu and Ma [13] claim that the foodrelated risk is perceived as low and that it depends on the personality characteristics.

Dr inż. M. Niewczas-Dobrowolska, Katedra Zarządzania Jakościa, prof. dr hab. T. Sikora, Katedra Zarzadzania Procesowego, Instytut Nauk o Jakości i Zarzadzania Produktem, Uniwersytet Ekonomiczny w Krakowie, ul. Rakowicka 27,31-510Kraków.Kontakt: niewczasm@poczta.onet.pl 
Consumers' concerns about food safety are mainly driven by food scandals and information shown by media.

Hawkes et al. [8] showed that, compared with other elements, the food-related risks were seen rather as low; the respondents indicated perceived risks in the following order: risk to their personal health (indicated as the first one), social risk (crime, drugs), risk to family (family member health, well-being), risk to their prosperity and food risk. The consumers' perception of food-related risks at a low level could be attributed to a statement that this risk is part of the risk of life. The consumers perceive it as a multi-factor issue; they take into account many non-scientific factors, such as effects of hazard or uncertainty.

Similarly to every process of perception, risk perception is determined by many factors. Those factors are shown in Fig. 1.

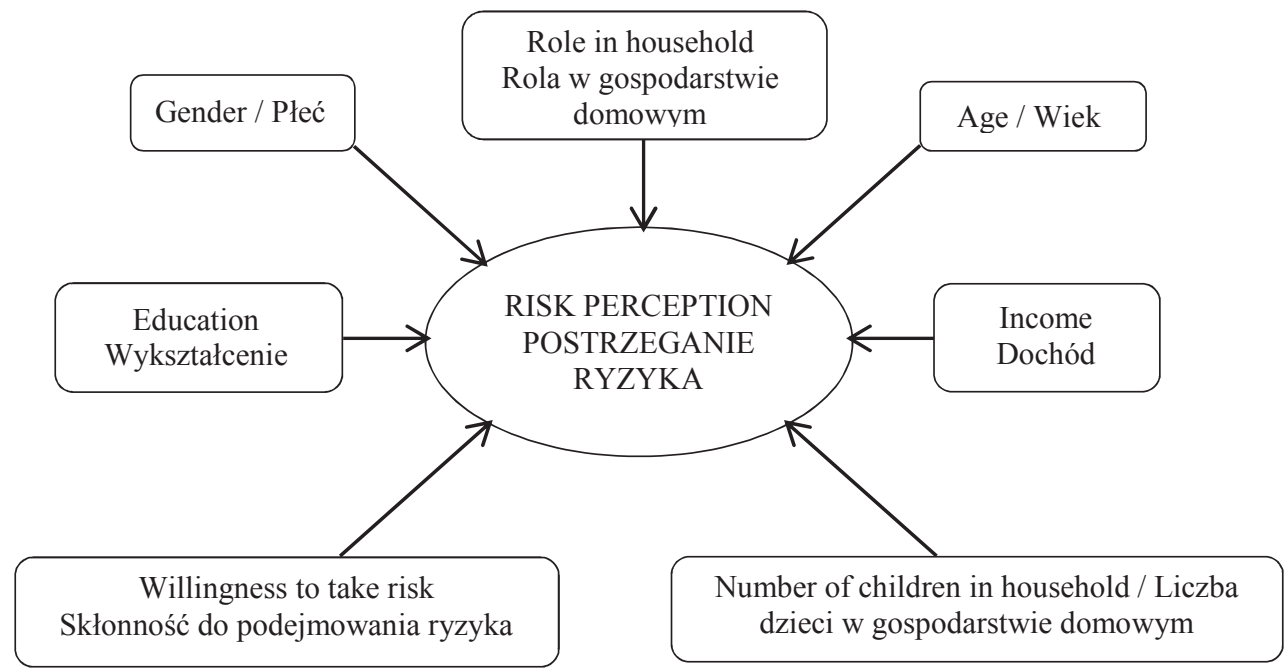

Fig. 1. Socio-economic and psychological factors affecting perception of risk

Rys. 1. Socjologiczne, ekonomiczne i psychologiczne czynniki wpływające na postrzeganie ryzyka Source / Źródło: the author’s own study / opracowanie własne

According to Finucane et al. [6], men perceive risk as lower than do women. This is also confirmed by scientists and experts in this field. White people also evaluate risks lower than the people of other races. Moreover, differently to the whites, men and women of other races perceive risk in the same way. White men assess risk as lower, because they can prioritize risk characterized by their reliance on new technologies. Also, the perception of food as a source of danger is influenced by the presence of children in a household. The respondents, who live at home with children, attach 
a much greater role to food-related risks than those living without them. The respondents who bring up small children pay special attention to food as a source of hazard. Housewives, who take care of home and family on a daily basis, pay more attention to food safety than those, who work outside their homes. Young consumers generally perceive the risks as minor. Among the people aged 55 years and more a tendency was found to assess food risk as high. As regards the level of education, a person with a higher level of education perceives food risks as lower. The same correlation is in the case of income - the higher the income, the lower the degree of risk perception; this can be explained by a higher likelihood of purchasing products (usually more expensive), which in respondents' opinion are safer or minimize the risk.

The way consumers perceive risk can be included in one of the three categories as indicated below [24]:

1. The risk associated with the technology is less acceptable than the risk caused by our activities.

2. One's risk of meeting a problem is lower than the average risk.

3. The known risk is less dangerous than the unknown one.

Risk perception is subjective and depends, among others, on the psychological characteristics of a person, knowledge, an object that is a source of risk, experience, etc. The perception of risk refers to an assessment made by the consumer, who expects to be exposed to the hazard and the consequences of its severity. Generally consumers, who assess a risk, are focused on the severity of effects rather than on the likelihood of hazard occurrence [23]. Vulnerability to the risk is associated with the consumer's willingness to take risk.

Consumers, who perceive a high food risk, will look for a type of food, in which the risk can be minimized or eliminated. For example consumers, who are afraid of pesticides contained in the 'conventional' food, want to buy 'eco food' for they can be sure they would avoid the risk [22]. Based on the research by Carvahlo et al. [1], a risk perception process is also determined by a country of origin and cultural similarity. Where it is highly probable that a food risk may appear, consumers perceive the risk as high when the product comes from a country showing cultural similarities to their own country. Then, consumers more often take actions to protect themselves against risk effects. The authors believe that when a hazard occurs in a country supplying goods to the consumer's country, it would be recommended to point out the psychological similarities between the citizens of those two countries in order to make the process of risk communication more efficient.

As Pennings et al. [17] say, consumers can be characterized by the risk perception and the willingness to take risk. According to those two factors, in the case of food hazard, a plan of action should be drafted to deal with it. Should the consumers in a particular country be characterized by a risk averse attitude (e.g. German consumers), 
decisive actions should be taken, such as the withdrawal of the product from the market. On the other hand, when consumers base their decisions on risk perception, special attention should be paid to the role of risk communication (e.g. consumers in Denmark and the USA). German consumers are characterized by a high risk aversion (they vehemently reacted to the BSE crisis and stopped buying beef). They see more risks than consumers from other countries. Compared with the Danish consumers or those from the USA, German consumers do not trust the state authorities involved in food safety. When facing a hazard to the food, the Danish consumers decided to reduce the risk of food consumption on the basis of perceived risk, whereas the consumers in the USA based their decisions on the willingness to take risk and the German consumers took those two risk types into consideration.

It is worth mentioning what factors cause social panic as a consequence of risk even when the hazard is relatively small. This process consists of the following elements [20]:

1. Fear factors - refer to the perception of seriousness and severity of the hazard by consumers. They can be caused by an unwitting exposure to any risk without the knowledge about it - e.g. consumers are afraid of chemicals and their residues in food that cannot be identified and to which they are exposed without their knowledge. The fear is greater when such an event is more inevitable, for example BSE and dioxin cannot be removed by washing and thermal treatment. There are divergent opinions of experts, politicians and producers about the hazard.

2. Panic factors - relate to the nature of risk, i.e. whether the hazard is new, unknown or it leads to damage to life or harm to health, and whether it applies to all people or to selected groups only.

3. Media - provide not always confirmed information about culprits and in this way they increase the uncertainty and panic among the public.

The objective of this paper was to show how consumers perceive the risk of some selected food hazards.

\section{Material and methods}

To assess the perception of food-related risk, a PFRI (Perceived Food Risk Index) psychometric questionnaire was applied. It was developed by Fife-Schaw and Rowe [5]. The PFRI makes it possible to assess the perception of risk among consumers. This method makes it possible to measure 10 factors that influence a risk perception process. They are as follows: probability of harm to health; concern about hazard; scientists' knowledge about hazard; ease of communicating information about hazard; responsibility-sharing in protection against hazard; frequency of consuming a hazardous product; correlation between the severity of hazard and the quantity of consumed food; 
supervision/control of food consumption; determination whether the hazard is natural or caused by human activities; severity of health effects of hazard $[3,5,10]$.

A paper survey was applied as a research tool. The survey was conducted in November 2016 and included 152 consumers from three regions of Poland: western, southern and central region. The respondents were students aged 21 to 23 years. The structure of the respondents is shown in Tab. 1.

Table 1. Socio-demographic structure of respondents Tabela 1. Struktura socjodemograficzna respondentów

\begin{tabular}{|c|c|c|}
\hline \multicolumn{2}{|c|}{ Groups of respondents / Grupy respondentów } & {$[\mathrm{N}]$} \\
\hline \multirow{2}{*}{ Gender / Płeć } & Women / Kobiety & 90 \\
\hline & Men / Mężczyźni & 62 \\
\hline \multirow{5}{*}{$\begin{array}{l}\text { Size of household } \\
\text { Wielkość gospodarstwa do- } \\
\text { mowego }\end{array}$} & A 1-person / 1-osobowe & 2 \\
\hline & A 2-person / 2-osobowe & 18 \\
\hline & A 3-person / 3-osobowe & 37 \\
\hline & A 4-person / 4-osobowe & 45 \\
\hline & More than 4 persons / Więcej niż 4-osobowe & 50 \\
\hline \multirow{3}{*}{$\begin{array}{l}\text { Place of residence } \\
\text { Miejsce zamieszkania }\end{array}$} & Village / Wieś & 56 \\
\hline & $\begin{array}{l}\text { City with less than } 100,000 \text { inhabitants } \\
\text { Miasto poniżej } 100 \text { tys. mieszkańców }\end{array}$ & 59 \\
\hline & $\begin{array}{l}\text { City with more than } 100,000 \text { inhabitants } \\
\text { Miasto powyżej } 100 \text { tys. mieszkańców }\end{array}$ & 37 \\
\hline \multirow{4}{*}{$\begin{array}{l}\text { Net income per person } \\
\text { Dochód netto na osobę }\end{array}$} & Below 800 zł / Poniżej 800 zł & 23 \\
\hline & $801-1200 \mathrm{zl}$ & 41 \\
\hline & $1201-1600 \mathrm{zl}$ & 49 \\
\hline & More than $1600 \mathrm{zl} /$ Więcej niż $1600 \mathrm{zl}$ & 35 \\
\hline
\end{tabular}

Source / Źródło: the authors' own study / opracowanie własne

The respondents were requested to assess the probability of risk associated with the GM food, hormone residues, food preservatives and trans fats, with the use of a 5-point scale. The factors were as indicated below:

1) probability of harm to health, where the probability was: 1 - low; 2 - quite low; 3 - moderate; 4 - quite high; 5 - high;

2) concern about hazard, where there was: 1 - lack of concerns; 2 - just a few concerns; 3 - some concerns; 4 - many concerns; 5 - a very high number of concerns;

3) scientists' knowledge about hazard, where there was: 1 - lack of knowledge; 2 - little knowledge; 3 - moderate knowledge; 4 - fairly good knowledge; 5 - sufficient knowledge; 
4) ease of communicating information about hazard, where the hazard was: 1 - never communicated; 2 - seldom communicated; 3 - sometimes communicated; 4 communicated to some extent; 5 - definitely communicated;

5) responsibility-sharing in protection against hazard, where the responsibility was: 1 - respondent's own; 2 - predominantly respondent's own; 3 - shared by the respondent and the authorities; 4 - almost entirely on the side of the authorities; 5 - entirely on the side of the authorities;

6) frequency of consuming a hazardous product, which was: 1 - very seldom; 2 - seldom; 3 - moderate; 4 - often; 5 - very often;

7) correlation between the severity of hazard and the quantity of consumed food, where hazardous was: 1 - even a very small quantity; 2 - small quantity; 3 - large quantity; 4 - very large quantity; 5 - the quantity did not present any hazard;

8) supervision/control of food consumption, where there was: 1 - lack of control; 2 - some control; 3 - moderate control; 4 - good control, 5 - full control;

9) determination whether the hazard is natural or caused by human activities, where the hazard was: 1 - natural; 2 - natural to some extent; 3 - both natural and caused by human activities; 4 - mainly caused by human activities; 5 - wholly caused by human activities;

10) severity of health effects of hazard, where there was: 1 - lack of consequences; 2 - little consequences; 3 - moderate consequences; 4 - quite high consequences; 5 - many consequences.

\section{Results and discussion}

Looking at the general assessment by the respondents from the three regions (Fig. 2), it should be noted that the highest perceived risk was associated with the determination whether the hazard is natural or caused by human activities - the sum of average ratings was 15.7, and in case of scientists' knowledge about hazard - the sum of average ratings was 14.7. The lowest perceived risk was associated with the correlation between the severity of hazard and the quantity of consumed food - the sum of average ratings was 11.2, and with the supervision/control of food consumption - the sum of average ratings was 11.6. The highest perceived food risk was perceived for food preservatives - the sum of average ratings was 34.2; the lowest was for trans fats - the sum of average ratings was 32.5 .

Taking into consideration the assessment made by the respondents from the western region in Poland (Fig. 3), it has been noted that the highest perceived risk was associated with the determination whether the hazard is natural or caused by human activities - the sum of average ratings was 16 , and in the case of scientists' knowledge about hazard - the sum of average ratings was 15.5. The lowest perceived risk was associated with the ease of communicating information about the hazard - the sum of 
average ratings was 9.9, and with the supervision/control of food consumption - the sum of average ratings was 10.7. The highest perceived food risk was perceived for food preservatives - the sum of average ratings was 34; the lowest was for trans fats the sum of average ratings was 32.9 .

Looking at the assessment made by the respondents from the central region in Poland (Fig. 4), it has been stated that the highest perceived risk was associated with the determination whether the hazard is natural or caused by human activities - the sum of average ratings was 15.8 , and in the case of scientists' knowledge about hazard - the sum of average ratings was 14.8. The lowest perceived risk was associated with the correlation between the severity of hazard and the quantity of consumed food - the sum of average ratings was 11.6, and with the supervision/control of food consumption - the sum of average ratings was 12. The highest perceived food risk was perceived for food preservatives - the sum of average ratings was 34.7; the lowest was for trans fats - the sum of average ratings was 33.3.

Looking at the assessment made by the respondents from the southern region in Poland (Fig. 5), it has been concluded that the highest perceived risk was associated with the determination whether the hazard is natural or caused by human activities the sum of average ratings was 15.2, and in the case of the probability of harm to health - the sum of average ratings was 14.3. The lowest perceived risk was associated with the correlation between the severity of hazard and the quantity of consumed food - the sum of average ratings was 11 , and with the supervision/control of food consumption - the sum of average ratings was 11.7. The highest perceived food risk was perceived for food preservatives - the sum of average ratings was 33.6; the lowest was for trans fats and GM foods - the sum of average ratings was 32.2.

The consumers can be divided into 2 groups - those characterized by high risk perception and those distinguished by low risk perception. While making their judgments, the consumers consider the benefits the product or the technology offer and the potential risk-related hazards. When it comes to the GM food, the perception of risk and benefit is interdependent. The dependence is negative, which means that most of the consumers perceive many hazards and little benefits. They give far more consideration to the information about potential hazards than to that about benefits [2].

According to Knight and Warland [11], food safety resides in public perception regardless of the steps farmers, businesses and government agencies take to ensure a safe food supply. Consumers perceive themselves as less vulnerable to food-related risks than other risks. De Sousa Carvalho Rossi et al. [4] conducted a survey on food risk perception among food handlers. They showed that the surveyed food handlers demonstrated a moderate risk perception of food safety, however the perception of the personal risk or risk to their peers was lower. 


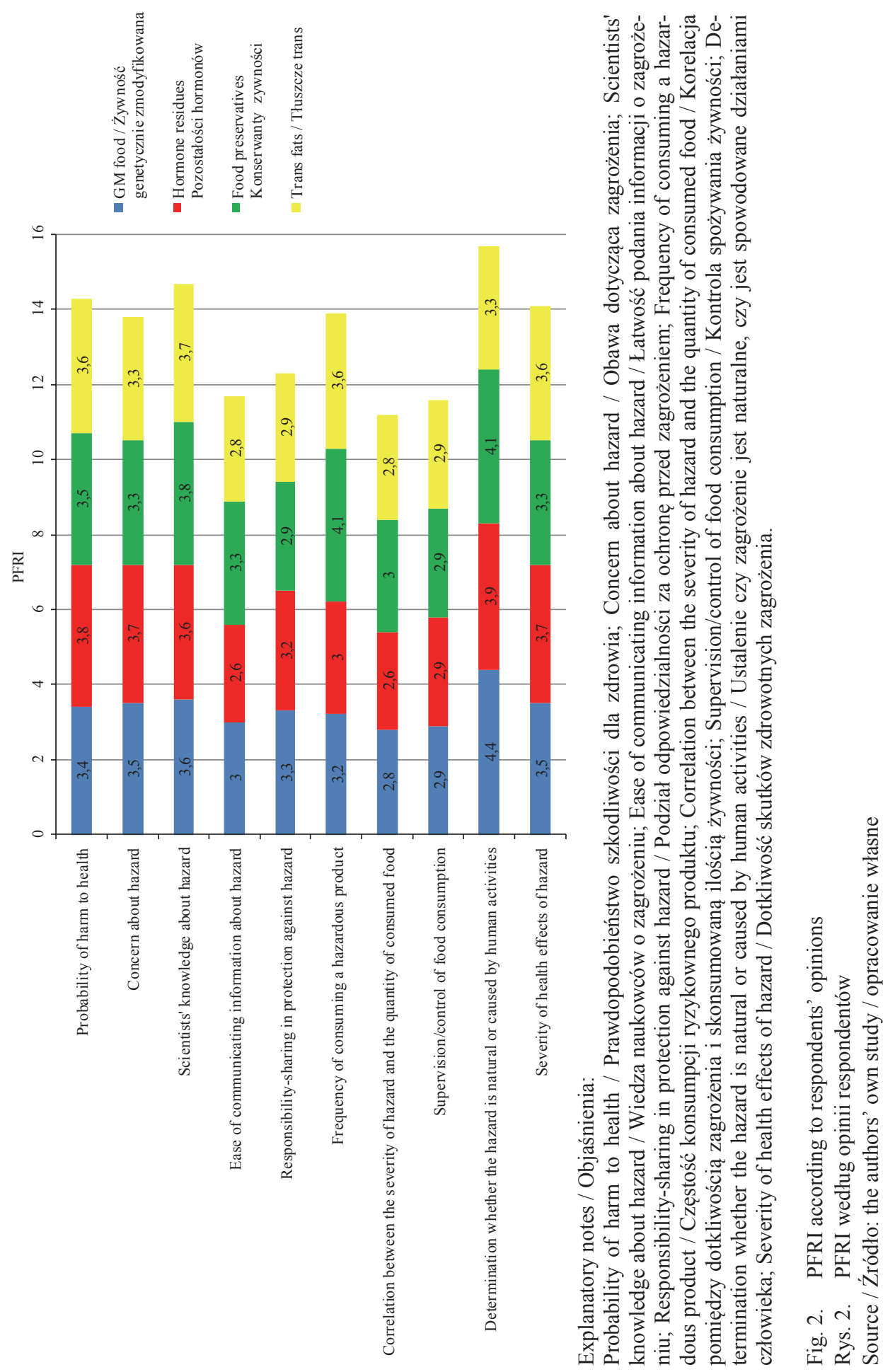



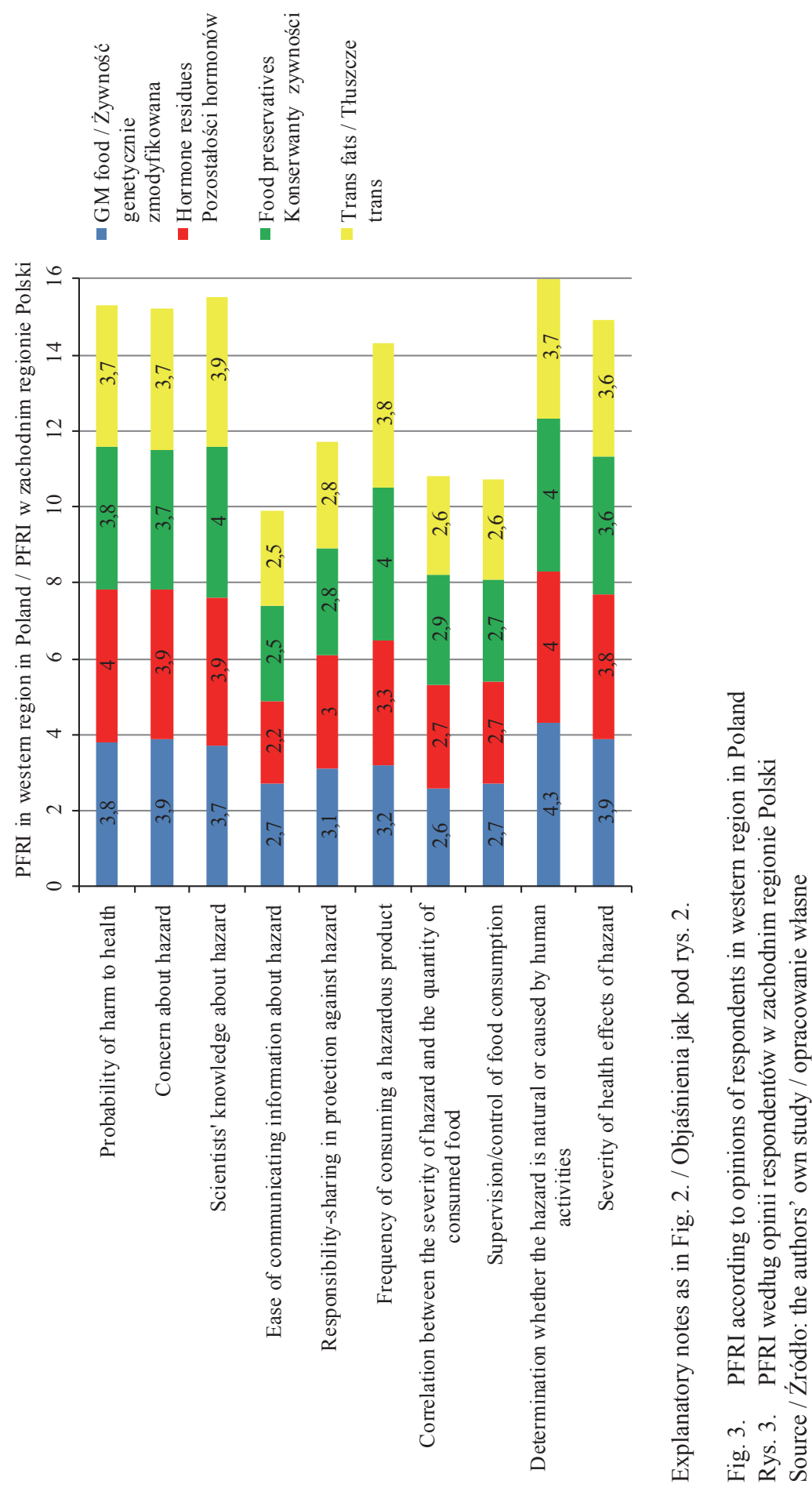

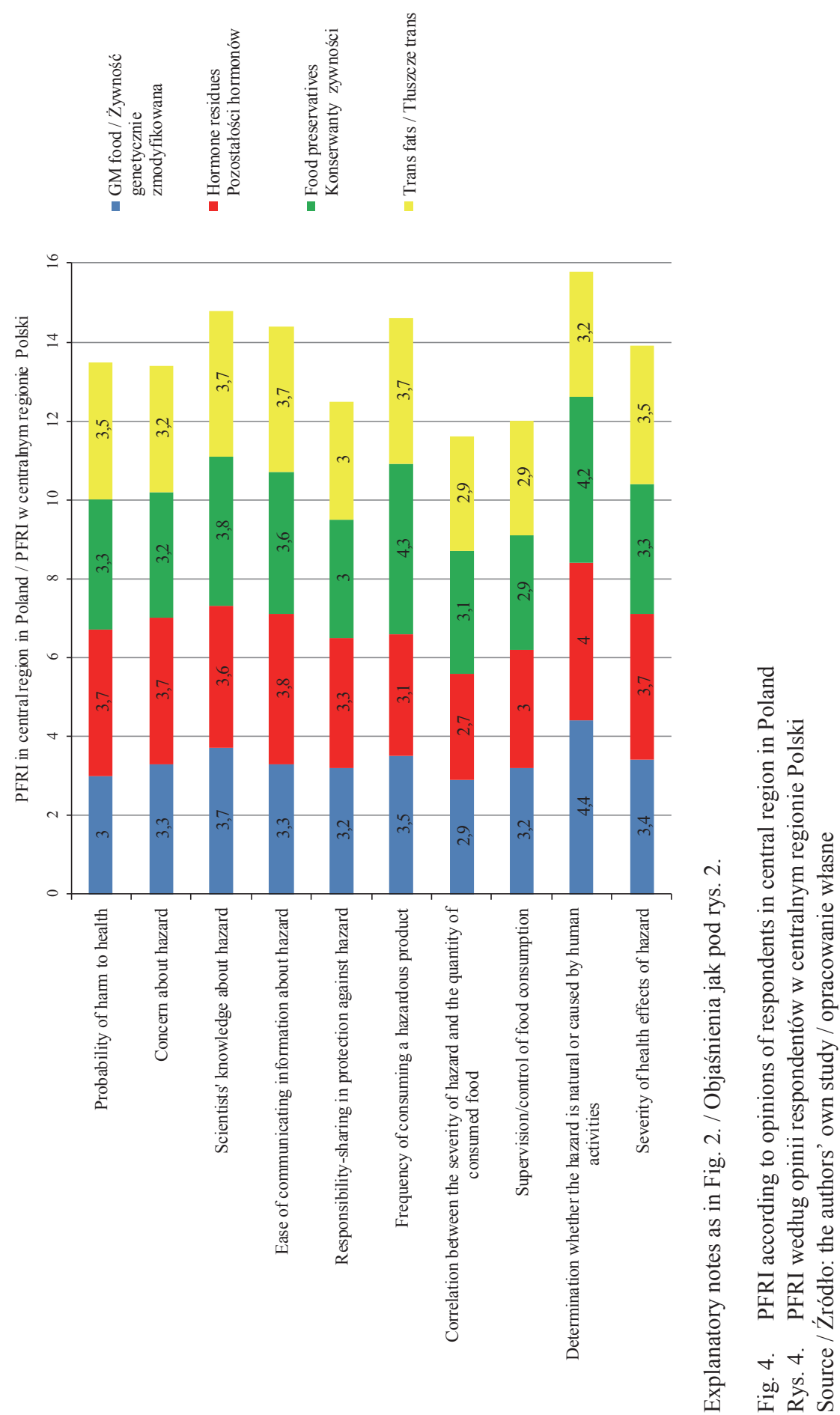

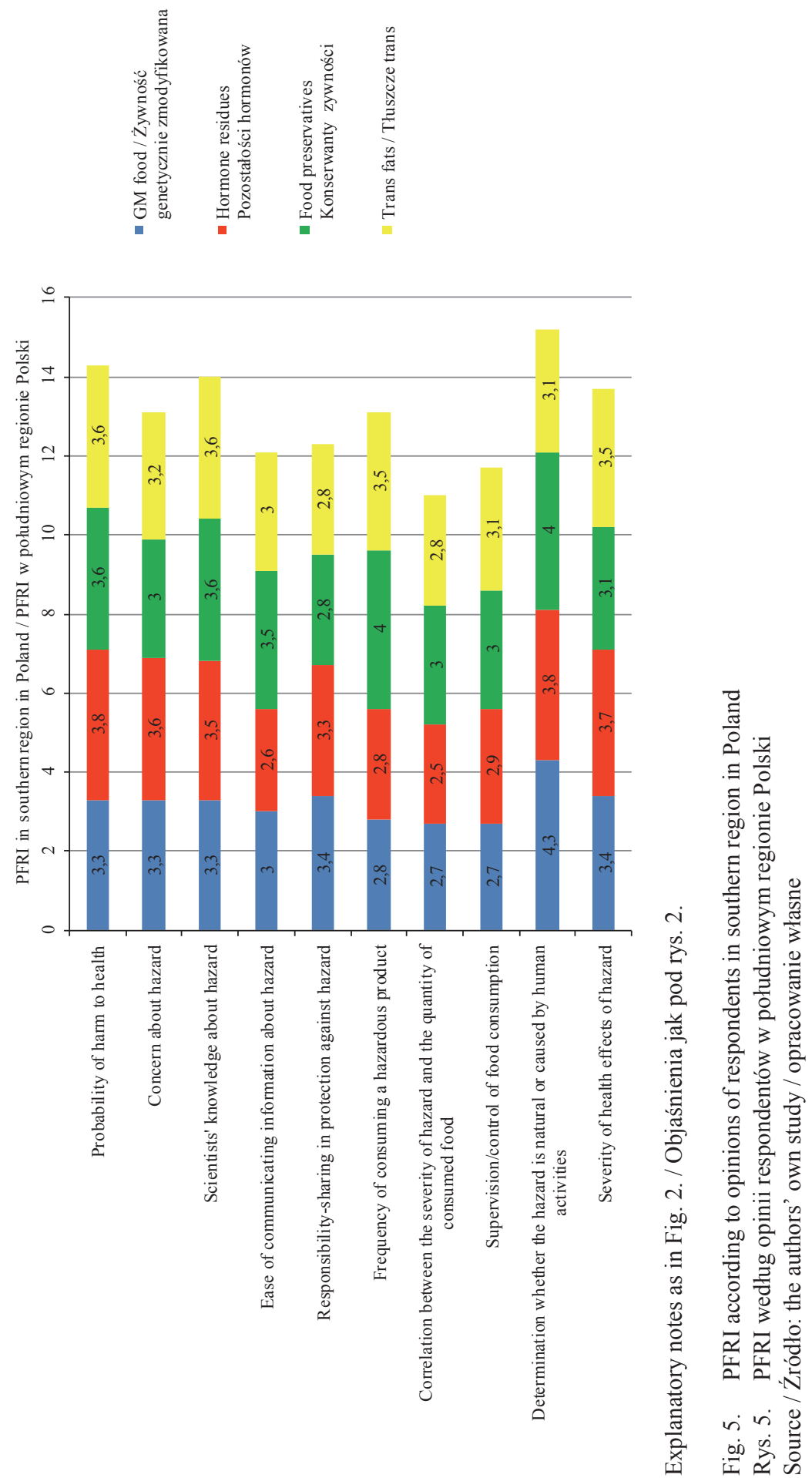
Niewczas conducted a survey research with the use of a questionnaire and surveyed 724 persons in Poland. The risk assessment scale was a 5-point scale where 5 meant the highest risk. The research-based conclusion was that consumers perceived the food risk dependently on the type of food product. The highest risk was attributed to fresh meat or meat products ( 4 on average); as next came fish and milk products perceived equally risky ( 3.1 on average for both of them), and little risk was associated with vegetables and fruits (2.3 on average) [15].

Heyao $\mathrm{Yu}$ et al. [9] showed that most consumers have concerns about foodborne illnesses associated with fresh-cut produce and they perceive the respective risk as high, however they perceive the probability of being infected with foodborne pathogens as low.

Tiozzo et al. [18] showed in their research that food risks were associated with specific attributes of food called quality warranties: freshness, naturalness and local provenance. In the opinion of the respondents, the expiry date and food conservation could cause food risks. Consumers focus their attention on the minimum shelf-life or expiration date [12]. Also, consumers are aware of various food risks. Furthermore, Whaley and Tucker [21] expressed an opinion that the main concerns about food referred mainly to: GMO, food bacteria and pesticide contamination.

\section{Conclusions}

1. According to the statements in PFRI, risk perception varies and depends on potential hazards.

2. In general, the highest perceived risk is associated with the determination whether the hazard is natural or caused by human activities.

3. The lowest perceived risk is usually associated with the correlation between the severity of hazard and the quantity of consumed food and also with the supervision/control of food consumption.

4. In all the regions surveyed the highest risk is perceived in association with food preservatives, whereas the lowest perceived risk - with trans fats. In the southern region in Poland, both trans fats and the GM foods are perceived in the same way as the lowest risk.

\section{References}

[1] Carvalho S.W., Block L.G., Sivaramakrishnan S., Manchanda R.V., Mitakakis C.: Risk perception and risk avoidance: The role of cultural identity and personal relevance. Int. J. Res. Marketing, 2008, 25, 319-326.

[2] Costa-Font J., Mossialos E.: Are perceptions of risks and benefits of genetically modified food (in)dependent? Food Quality Pref., 2007, 18, 173-182. 
[3] Cunha L.M., Moura A.P., Lopes Z., Santos M., Silva I.: Public perceptions of food-related hazards: An application to Portuguese consumers. British Food J., 2010, 11 (5), 522-543.

[4] De Sousa Carvalho Rossi M., Stedefeldt E., da Cunha D.T., de Rosso V.V.: Food safety knowledge, optimistic bias and risk perception among food handlers in institutional food services. Food Control, 2017, 73 (Part B), 681-688.

[5] Fife-Schaw C.R., Rowe G.: Public perceptions of everyday food hazards: A psychometric study. Risk Analysis, 1996, 16(4), 487-500.

[6] Finucane M.L., Slovic P., Mertz C.K., Flynn J., Satterfield T.A.: Gender, race, and perceived risk: the 'white male' effect. Health, Risk \& Society, 2000, 2, 159-172.

[7] Grunert K.G.: Current issues in the understanding of consumer food choice. Trends Food Sci. Technol., 2002, 13 (8), 275-285.

[8] Hawkes G., Houghton J., Rowe G.: Risk and worry in everyday life: Comparing diaries and interviews as tools in risk perception research. Health, Risk and Society, 2009, 11 (3), 209-230.

[9] Yu H., Neal J.A., Sirsat S.A.: Consumers' food safety risk perceptions and willingness to pay for fresh-cut produce with lower risk of foodborne illness. Food Control, 2018, 86, 83-89.

[10] Kirk S.F.L., Greenwood D., Cade J.E., Pearman A.D.: Public perception of a range of potential food risks in the United Kingdom. Appetite 2002, 38, 189-197.

[11] Knight A., Warland R.: The relationship between sociodemographics and concern about food safety issues. J. Consumer Affairs, 2004, 38 (1), 107-120.

[12] Krasnowska G., Salejda A.M: Ocena wiedzy konsumentów na temat znakowania żywności. Żywność. Nauka. Technologia. Jakość, 2011, 1 (74), 173-189.

[13] Liu P., Ma L.: Food scandals, media exposure, and citizens' safety concerns: A multilevel analysis across Chinese cities. Food Policy, 2016, 63, 102-111.

[14] Martinez-Poveda A., Molla-Bauza M.B., del Campo Gomis F.J., Martinez-Carrasco Martinez L.: Consumer-perceived risk model for the introduction of genetically modified food in Spain. Food Policy, 2009, 34 (6), 519-528.

[15] Niewczas M.: Postrzeganie możliwości wystąpienia zagrożenia dla zdrowia ze strony różnych grup żywności. Towaroznawcze Problemy Jakości, 2013, 2 (35), 43-53.

[16] Papadopoulos A., Sargeant J.M., Majowicz S.E., Sheldrick B., McKeen C., Wilson J., Dewey C.E.: Enhancing public trust in the food safety regulatory system. Health Policy, 2012, 107 (1), 98-103.

[17] Pennings J.M.E., Wansink B., Meulenberg M.T.G.: A note on modeling consumer reactions to a crisis: The case of the mad cow disease. Int. J. Res. Marketing, 2002, 19, 91-100.

[18] Tiozzo B., Mari S., Ruzza M., Crovato S., Ravarotto L.: Consumers' perceptions of food risks: A snapshop of the Italian Triveneto area. Appetite, 2017, 111, 105-115.

[19] Vasvari T.: Risk, risk perception, risk management - a review of the literature. Public Finance Quarterly, 2015, 1, 29-48.

[20] Verbeke W., Frewer L.L.J., Scholderer J., de Brabander H.F.: Why consumer behave as they do with respect to food safety and risk information. Analytica Chimica Acta, 2007, 586, 2-7.

[21] Whaley S.R., Tucker M.: The influence of perceived food risk and source trust on media system dependency. J. Applied Communications, 2004, 88 (1), 9-27.

[22] Williams P.R.D., Hammitt J.K.: Perceived risks of conventional and organic produce: Pesticides, pathogens, and natural toxins. Risk Analysis, 2001, 21 (2), 319-330.

[23] Yeung R.M.W., Morris J.: An empirical study of the impact of consumer perceived risk on purchase likelihood: A modelling approach. Int. J. Consumer Studies, 2006, 30 (3), 294-305.

[24] Zalewski R.I.: Zarządzanie jakością w produkcji żywności. Wyd. AE w Poznaniu, Poznań 2008. 


\title{
OCENA POSTRZEGANIA RYZYKA WYBRANYCH ZAGROŻEŃ W ŻYWNOŚCI PRZY WYKORZYSTANIU WSKAŹNIKA RYZYKA ŻYWNOŚCIOWEGO (PFRI)
}

\author{
Streszczenie
}

Postrzeganie ryzyka zależy od wielu czynników społeczno-ekonomicznych i psychologicznych. Bardzo ważne jest, aby wiedzieć, jak konsumenci postrzegają zagrożenia związane żywnością, takie jak: pozostałości hormonów, żywność zmodyfikowana genetycznie, konserwanty żywności, thuszcze trans. Przedstawiono narzędzie do pomiaru postrzegania ryzyka - wskaźnik postrzeganego ryzyka żywności (PFRI). Badanie zostało przeprowadzone wśród 152 młodych konsumentów w trzech regionach Polski w $2016 \mathrm{r}$.

Celem pracy było wykazanie, w jaki sposób konsumenci postrzegają wybrane zagrożenia bezpieczeństwa żywności. Stwierdzono, że najwyższe postrzegane ryzyko wiąże się z tym, czy zagrożenie jest naturalne czy też jest wynikiem działalności człowieka - suma średnich ocen wyniosła 15,7. W przypadku, gdy zagrożenie znane jest naukowcom - suma średnich ocen wyniosła 14,7. Najniżej postrzegane ryzyko związane było z zależnością między dotkliwością skutków zagrożenia a ilością spożywanej żywności suma średnich ocen wyniosła 11,2 oraz z kontrolą spożywanej żywności - suma średnich ocen wyniosła 11,6. Z przeprowadzonych badań wynika potrzeba i znaczenie pomiaru oraz gromadzenia informacji na temat postrzegania ryzyka żywności przez konsumentów. Postrzeganie ryzyka związanego z żywnością wpływa na ich wybory i zachowanie w sytuacji pojawienia się zagrożenia.

Słowa kluczowe: postrzeganie ryzyka, żywność, konsument, wskaźnik postrzeganego ryzyka żywności (PFRI) 